\title{
Effect of Aerated Compost Tea on the Growth Promotion of Lettuce, Soybean, and Sweet Corn in Organic Cultivation
}

\author{
Min Jeong Kim, Chang Ki Shim*, Yong Ki Kim, Sung Jun Hong, Jong Ho Park, Eun Jung Han, Jin Ho Kim \\ and Suk Chul Kim \\ Organic Agriculture Division, National Academy of Agricultural Science, Rural Development Administrations, Suwon 441- \\ 707, Korea \\ (Received on March 6, 2015; Revised on May 11, 2015; Accepted on May 12, 2015)
}

This study investigated the chemical characteristics and microbial population during incubation of four kinds of aerated compost teas based on oriental medicinal herbs compost, vermicompost, rice straw compost, and mixtures of three composts (MOVR). It aimed to determine the effects of the aerated compost tea (ACT) based on MOVR on the growth promotion of red leaf lettuce, soybean and sweet corn. Findings showed that the pH level and EC of the compost tea slightly increased based on the incubation time except for rice straw compost tea. All compost teas except for oriental medicinal herbs and rice straw compost tea contained more $\mathrm{NO}_{3}^{-} \mathrm{N}$ than $\mathrm{NH}_{4}^{+}-\mathrm{N}$. Plate counts of bacteria and fungi were significantly higher than the initial compost in ACT. Microbial communities of all ACT were predominantly bacteria. The dominant bacterial genera were analyzed as Bacillus (63.0\%), Ochrobactrum (13.0\%), Spingomonas $(6.0 \%)$ and uncultured bacterium $(4.0 \%)$ by $16 \mathrm{~S}$ rDNA analysis. The effect of four concentrations, $0.1 \%$, $0.2 \%, 0.4 \%$ and $0.8 \%$ MOVR on the growth of red leaf lettuce, soybean and sweet corn was also studied in the greenhouse. The red leaf lettuce with $0.4 \%$ MOVR had the most effective concentration on growth parameters in foliage part. However, $0.8 \%$ MOVR significantly promoted the growth of root and shoot of both soybean and sweet corn. The soybean treated with higher MOVR concentration was more effective in increasing the root nodule formation by 7.25 times than in the lower MOVR concentrations Results indicated that ACT could be used as liquid nutrient fertilizer with active microorganisms for culture of variable crops under organic farming condition.

\footnotetext{
*Corresponding author.

Phone) +82-61-238-2557, FAX) +82-61-238-3824

E-mail)ckshim@korea.kr
}

Keywords : aerated compost tea, growth promotion, lettuce, soybean, sweet corn

Organic cultivation techniques for crops production in the field and greenhouses have been developed in alternative production techniques which employ biological or organic compounds for disease and pest control (Litterick et al., 2004; Termorshuizen et al., 2006; Turemis, 2002).

Lately, current environmental issues are capturing the world's attention focusing on improving the environmental quality through the adoption of techniques and measures that have reduced impacts on the environment (Hamdar et al., 2000). Nutrient value of organic composts varies widely depending upon the nature of the composted feedstock. If the start material contains manure, most finished composts are richer in nitrogen and other nutrients and have better chemical characteristics (Abu-Zahra and Tahboub, 2008; Steinegger and Janssen, 1996). The role of organic matter is very important. Its high content in the soil influences physical properties (Mc Conenell et al., 1993; Uehara and Gilman, 1981); assures good value of soil cation exchange capacity (CEC); reduces the mobility of nutrients in soil solution (Duxbury et al., 1989), prevents the loss of useful substances by means of the action of enzymes; avoids the pollution of water table; improves soil porosity (Bauer and Black, 1994); helps the chemical stabilization of structure; and reduces the processes of soil erosion and increases the micro-organisms and enzymatic activity (Brown et al., 1993).

Composts may induce systemic resistance in plants (Pharand et al., 2002), and composted yard waste applied to soil prior to planting also reduces bacterial spot incidence on tomato fruit, although foliar disease is not reduced (Abbasi et al., 2002). Compost tea is one of the alternative techniques extracted from composted materials by steeping or brewing the compost in water using various preparation 
methods (Ingham, 2005; Litterick et al., 2004; Scheuerell and Mahaffee, 2002). Study on compost tea technology began in 1980's in USA, but field practices comparing the brewing methods are few. Historically, home-made extract of compost tea called "passive" or non-aerated compost tea (NCT) were prepared by suspending a bag of compost in a container of water for 14 days to extract anaerobic microbes and nutrients which are used and applied to promote plant health and vitality in plants (Ingham, 2005; Naidu, 2010; Scheuerell and Mahaffee, 2002). Recently, aerated compost tea has been brewed in large-scale mechanized equipment for shorter period of time and often supplemented with oxygen, nutrients, and microbial starter cultures to enhance the biological activity of the compost tea which contains aerobic microbes and nutrients (Ingham, 2005; Naidu et al., 2010; Scheuerell and Mahaffee, 2004).

Compost tea has been cited as an option for conventional and organic growers thought to enhance crop fertility by introducing microorganisms that might aid in soil nutrient retention and extraction, and by adding soluble nutrients, further adding to their potential value as a part of an integrated crop management plan (Diver, 2002; Ingham, 2005; Kannangara et al., 2006; Merrill and McKeon, 2001).

To date, majority of the studies have focused on plant disease control and suppressive ability of compost tea (Goonani et al., 2011; Litterick et al., 2004; Weltzien, 1992). A little plant disease control studies are available on aerated compost tea or non-aerated compost tea. Conforti et al. (2002) reported that a field practice at Presidio Golf Course, to assess the efficacy of aerated compost tea on turf grass growth and in suppressions of a common fungal disease, Michrodocim patch caused by Michrodocium nivale. Plamer et al. (2010) presented that aerated compost tea introduced from immature compost suppressed the growth of Botrytis cinerea on bean leaflets, with an abundant and diverse microbial community.

There are number of reports that some plant diseases have been partially suppressed by application of compost tea (Brinton et al., 2004; Scheuerell and Mahaffee, 2002). Al-Dahmani et al. (2003) demonstrated that the population density of Xanthomonas vesicatoria in infected leaves was reduced significantly by foliar sprays with compost extracts produced from composted cow manure. Zaller (2006) also reported that the use of foliar vermicompost extracts sprayed tomato plants showed clear signs of Phytophthora infestans infection as water sprayed plants; the severity of the infection was unaffected by the two spraying treatments produced from fruit, vegetable and cotton waste by redworms (Eisenia fetida Sav.).

In other studies, however, suppression has been highly variable between different batches or batch preparations (Scheuerell and Mahaffee, 2004, 2006). Potential problems such as pathogen or chemical contamination of crops by application of compost tea have also been documented in recent scientific studies (Ingram and Millner, 2007; Rahel et al., 2007).

The objectives of this study was to determine the efficacy dose of application and evaluated the efficacy of aerated compost teas prepared from oriental medicinal herbs compost, vermicompost, rice straw compost, and mixtures of three composts (MOVR) on the growth promotion of red leaf lettuce, sweet corn and soybean in the greenhouse.

\section{Materials and Methods}

Preparation of plant materials. Red leaf lettuce, beet and sweet corn seeds were obtained from commercial seed company in Korea. Twenty seeds of red leaf lettuce, beet and sweet corn were sown in 72 holes nursery trays using horticultural nursery media based with coconut beat and peat moss. The seedling of each crop was regularly watered as required. Temperature and relative humidity in the greenhouse were $28^{\circ} \mathrm{C}$ and $80 \%$, respectively under $18 / 6 \mathrm{~h}$ (light/dark) photoperiod.

Preparation of composted materials and compost tea. Three types of organic compost materials, rice straw compost, vermicompost and Hinoki cypress bark compost were prepared using same materials and allowed to mature for two years using windrow composting system. The organic compost mixtures (MOVR) obtained from two-year old composted rice straw compost, vermicompost and Hinoki cypress bark compost were used for the production of aerated compost tea. Aerated compost tea was prepared by mixing one liter of homogenized compost mixture with 101 of tap water (from agricultural well) in a 201 handmade compost tea brewer. Actively aerated compost tea was allowed to brew at room temperature for four days of incubation in 201 of handmade compost tea brewer with air pump. Following the incubation period, actively aerated compost was filtered through two-layer 800 micron mesh bag which reduces the chance of clogging application equipment for foliage spray.

Analysis of chemical properties of aerated compost tea. The $\mathrm{pH}$ level and electrical conductivity (EC) of the aerated compost tea were measured in each batch of $1: 1(\mathrm{v} /$ v) mixture of deionized water: aerated compost tea using a conductivity/pH meter (3200 M Multi-Parameter Analyzer, Agilent Technologies, U.S.A.). Mineral N ( $\mathrm{NH}_{4}-\mathrm{N}$, and 
$\mathrm{NO}_{3}-\mathrm{N}$ ) of the aerated compost tea was analyzed calorimetrically using a discrete analyzer (Easy Chem Plus, Systea Scientific, IL).

Analysis of microbial population density of compost tea. Microbial population density of each aerated compost tea was analyzed on three samples from three separate events by extraction methods. Compost tea samples were taken after $24 \mathrm{~h}$ brewing cycle for each aerated compost tea. One milliliter sample of each aerated compost tea was transferred into $9 \mu \mathrm{l}$ distilled water. The $100 \mu \mathrm{l}$ of serial dilution of each compost tea was spread evenly on four plates of nutrient agar (NA, nutrient broth; $8 \mathrm{~g}$, agar; $15 \mathrm{~g}$, distilled water 1 1) (Difco, USA), potato dextrose agar (PDA, potato starch; $4 \mathrm{~g}$, dextrose; $20 \mathrm{~g}$, agar; $15 \mathrm{~g}$, distilled water 1 1) (Difco, USA) and rose bengal agar (RBA) based PDA and added $67 \mathrm{mg} / 1$ rose bengal (Smith and Dawson, 1944). After incubation at $25^{\circ} \mathrm{C}$ for $24 \mathrm{~h}$, population densities were reported as colony forming unit (cfu)/ml from each media.

Identification of bacterial isolates by $16 \mathrm{~S}$ rDNA sequencing. A single colony of purified each isolate was inoculated into $9 \mathrm{~mL}$ LB media and incubated in shaker incubator at $27^{\circ} \mathrm{C}$ for 5 days with constant shaking (180 $\mathrm{rpm}) .100$ to 1,200 purified isolates were randomly picked, checked for purity, and stored in $25 \%$ glycerol at $-80^{\circ} \mathrm{C}$ until further analysis.

Genomic DNA was extracted using enzymatic lysis and alkaline hydrolysis method as modified by Kim et al. (2011). A $1 \mathrm{ml}$ of bacterial cells was lysed in $200 \mu \mathrm{l}$ of lysis buffer (0.05 M Tris-HCl, $1 \mathrm{mM}$ EDTA, pH 7.5) containing $0.5 \mathrm{mg}$ of lysozyme (Sigma-Aldrich Chemie $\mathrm{GmbH}$, Schnelldorf, Germany) by incubation for $1 \mathrm{~h}$ at $37^{\circ} \mathrm{C}$. After addition of $10 \mu \mathrm{l}$ of each of $1 \mathrm{M} \mathrm{NaOH}$ and $10 \%$ sodium dodecyl sulfate, the mixture was incubated at $95^{\circ} \mathrm{C}$ for 10 min and neutralized with $10 \mu \mathrm{l}$ of $1 \mathrm{M} \mathrm{HCl}$. Nucleic acids were then purified using the QIAamp DNA bacteria mini kit (Qiagen, Basel, Switzerland), resulting in a sample volume of $100 \mu \mathrm{l}$.

The 16S rRNA gene was amplified using conventional PCR with primers fD1 (5'-AGAGTTTGATCCTGGCTCAG-3') and rP2 (5'-ACGGCTACCTTGTTACGACTT-3'), producing an amplicon of approximately 1,500 bp (Weisburg et al., 1991). Cycling parameters included an initial denaturation for $5 \mathrm{~min}$ at $95^{\circ} \mathrm{C}, 40$ cycles of $1 \mathrm{~min}$ at $94^{\circ} \mathrm{C}, 1 \mathrm{~min}$ at $60^{\circ} \mathrm{C}$, and $1 \mathrm{~min}$ at $72^{\circ} \mathrm{C}$, and a final extension for $10 \mathrm{~min}$ at $72^{\circ} \mathrm{C}$. Five microliters of the DNA extract was used for amplification in a total volume of $50 \mu \mathrm{l}$ containing 1.25 U of AmpliTaq DNA polymerase LD (Applied Biosystems, Rotkreuz, Switzerland), and the appro- priate buffer. Amplicons were purified with the QIAquick PCR purification kit (Qiagen AG, Basel, Switzerland) and sequenced with forward primer fD1 using the BigDye kit and an automatic ABI Prism 3730 Genetic Analyzer (Applied Biosystems, Rotkreuz, Switzerland).

PCR products were purified and sequenced from both ends using an ABI 3730 automated sequencer (Applied Biosystems Inc., Rotkreuz, Switzerland). The sequences were manually checked for quality, assembled, trimmed, and aligned using BioEdit (http://www.mbio.ncsu.edu/ bioedit/bioedit.html). The sequences were subjected to Blast searches against the NCBI database.

Evaluation of plant growth with compost tea. Four treatments at the rate of $50 \mathrm{ml}$ per plant were applied in the early morning every week for four weeks starting three days after transplanting (DAT) each crop seedlings to the root zone and foliage of plants. The compost tea extraction ratio was $1: 1(\mathrm{v} / \mathrm{v})$ aerated compost tea to tap water and 50 $\mathrm{mL}$ of aerated compost tea was applied to the root zone and was applied to the foliage. Aerated compost teas were prepared separately events every week before application using the same batch of the mixture of four compost materials in a shade close to the greenhouse. Plants were harvested five weeks after treatment. The quantitative properties of red leaf lettuce, sweet corn, and soybean were determined in each plant by measuring the fresh weight and leaf number, leaf length, leaf width or shoot, and root length of the tested crops.

Experimental design and statistical analysis. Experiments were conducted using a completely randomized design with 15 replicates of each treatment. Pairwise comparisons between treatments were performed using the least significant difference test. When significant differences were observed $(p \leq 0.001)$, treatment means experiments were separated using Fisher's least significant differences (LSD) test at $95 \%$ confidence level $(p \leq 0.05)$ using the Statistical Analysis System, version 9.1 (SAS statistical analysis software, SAS Institute Inc. Cary, NC).

\section{Results and Discussion}

Chemical properties of aerated compost teas. The changes in $\mathrm{pH}$ level and electronic conductivity (EC) of the compost teas are shown in Fig. 1. After a day of incubation, $\mathrm{pH}$ levels of all aerated compost teas slightly increased (2.2-9.9\%) in the following order, rice straw compost, oriental medicinal herbs compost, vermicompost, and MOVR during incubation period (Fig. 1A). Vermicompost tea and 

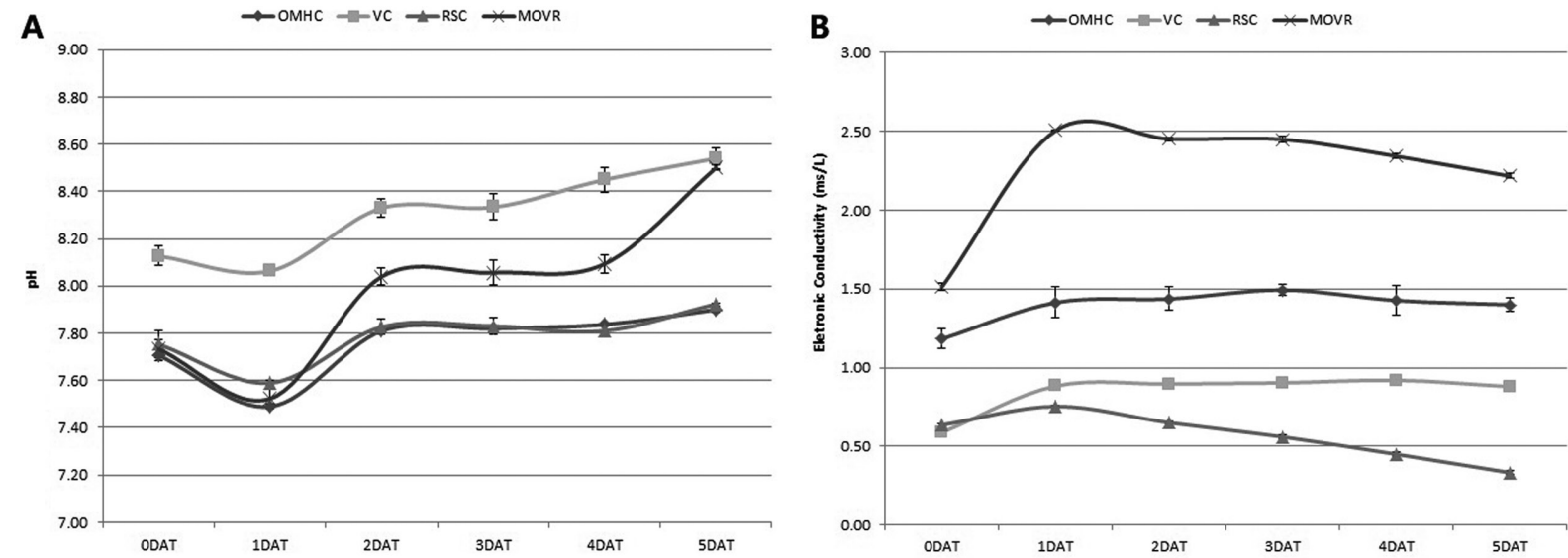

Fig. 1. Changes in mean values of pH (A) and E.C (B) of aerated compost tea for 5 days after brewing with air pump. Error bars represent standard errors of the mean $(n=4)$. DAT, days after treatment; OMHC, oriental medicinal herbs compost; VC, vermicomposting; RSC, rice straw compost; and MOVR, mixture of OMHC, SRC and VC.

oriental medicinal herbs compost tea had the highest and lowest $\mathrm{pH}$ levels $\mathrm{pH} 8.54( \pm 0.88)$ and $\mathrm{pH} 7.90( \pm 0.88)$, respectively for five days after aeration (Fig. 1A). Also, the $\mathrm{EC}$ values of all aerated compost teas except for the rice straw compost tea significantly increased (18.3-49.2\%) after one day incubation (Fig. 1B). Highest EC level was observed in the mixture of oriental medicinal herbs compost and vermicompost scored $2.22 \mathrm{~ms} / \mathrm{l}( \pm 0.01)$ for five days after incubation (Fig. 1B). Likewise, the EC values for rice straw compost tea significantly decreased from $0.64 \mathrm{~ms} / 1$ to $0.33 \mathrm{~ms} / \mathrm{l}$ after incubation (Fig. 1B).

Koné et al. (2010) reported that $\mathrm{pH}$ of non-aerated compost tea ranged from 5.92 (sheep manure) to 6.57 (chicken manure) and the highest EC was found in chicken manure $(1.05 \mathrm{~ms} / \mathrm{l})$ compost tea followed by seaweed compost tea (0.48 ms/l). Also, Haggag and Saber (2007) described that the $\mathrm{EC}$ and $\mathrm{pH}$ of compost tea based on plant residues (rice ash, bean straw, and vegetative food waste) was higher than chicken manure. However, Pant et al. (2011) reported that application of vermicompost teas did not affect $\mathrm{pH}$, but significantly increased EC, N and K content of Pak Choi growth media. Hence, physical and chemical properties of nutrients in the compost tea could improve the nutritional status of the plants (Koné et al., 2010).

Fig. 2 shows the changes in soluble nitrogen types, $\mathrm{NO}_{3}^{-}-\mathrm{N}$ and $\mathrm{NH}_{4}^{+} \mathrm{-N}$ of the compost teas. All compost teas except for oriental medicinal herbs compost tea contained more $\mathrm{NO}_{3}^{-}-\mathrm{N}$ type of nitrogen than $\mathrm{NH}_{4}^{+}-\mathrm{N}$ type of nitrogen. Among the compost teas, rice straw compost tea had very low $\mathrm{NO}_{3}^{-}-\mathrm{N}$ and $\mathrm{NH}_{4}^{+}-\mathrm{N}$ nitrogen contents scored $4 \mathrm{mg} /$ 1 and $1 \mathrm{mg} / \mathrm{l}$, respectively, for 5 days after brewing. Moreover, rice straw and oriental medicinal herbs compost tea had very low $\mathrm{NO}_{3}^{-}-\mathrm{N}$ nitrogen contents compared to the other compost teas. The highest $\mathrm{NO}_{3}^{-}-\mathrm{N}$ nitrogen content
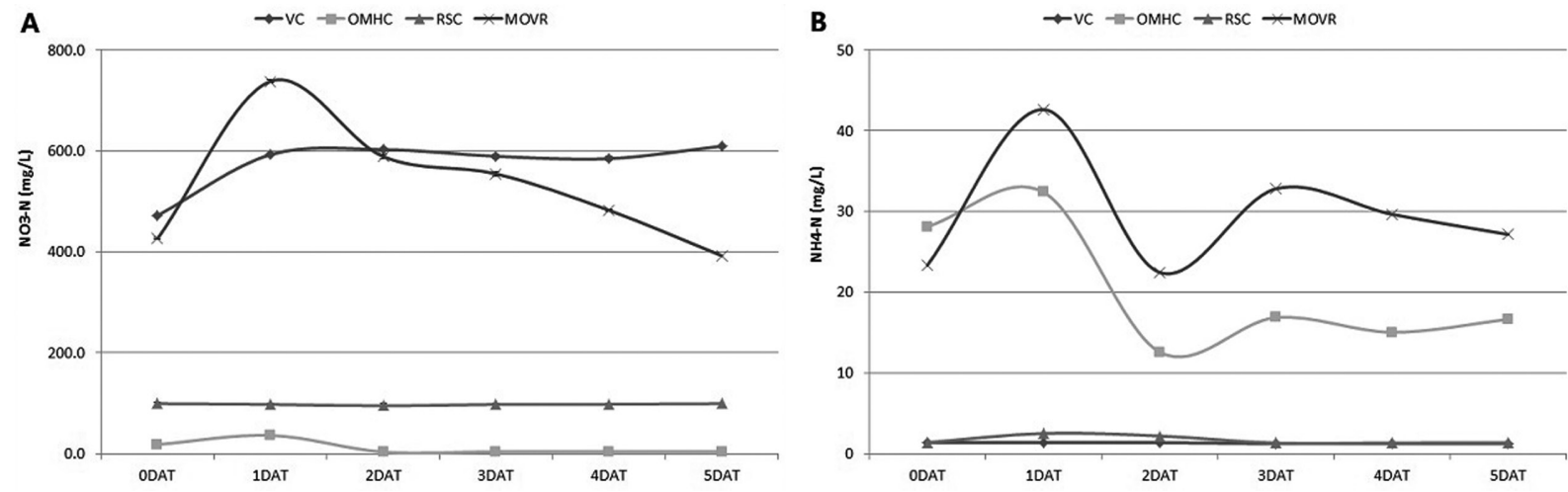

Fig. 2. Comparison of mean values of $\mathrm{NO}_{3}^{-}-\mathrm{N}(\mathrm{A})$ and $\mathrm{NH}_{4}^{+}-\mathrm{N}(\mathrm{B})$ of four compost tea at room temperature for 5 days after brewing with air pump. Error bars represent standard errors of the mean $(n=4)$. DAT, days after treatment; OMHC, oriental medicinal herbs compost; VC, vermicompost; RSC, rice straw compost; MOVR, mixtures of OMHC, SRC and VC. 

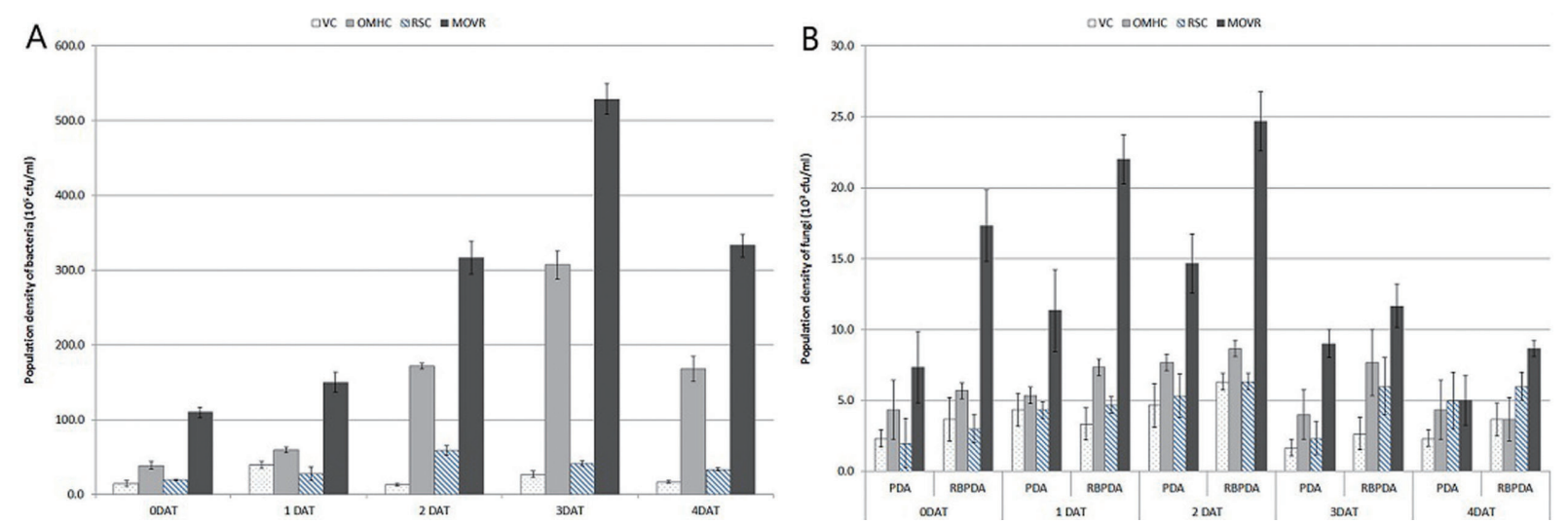

Fig. 3. Changes of microbial population density of aerated compost tea at room temperature for 4 days after brewing with air pump. Error bars represent standard errors of the mean $(n=4)$. CFU, colony forming unit; DAT, days after treatment; OMHC, oriental medicinal herbs compost; VC, vermicomposting; RSC, rice straw compost; MOVR, mixture of OMHC, SRC and VC; NA, Nutrient Agar; PDA, Potato Dextrose Agar; RBPDA, PDA added Rose Bengal (60 mg/l).

was observed in vermicompost tea scored as $609.4( \pm 4.1)$ $\mathrm{mg} / \mathrm{l}$ after 2 days aeration (Fig. 2A). The mixture of oriental medicinal herbs compost and vermicompost highly decreased from $737.7 \mathrm{mg} / 1$ to $392.4 \mathrm{mg} / \mathrm{l}(-46.8 \%)$ after one day incubation (Fig. 2A).

The MOVR had the highest $\mathrm{NH}_{4}^{+}-\mathrm{N}$ nitrogen contents scored $27( \pm 2.0) \mathrm{mg} / \mathrm{l}$ for 5 days after incubation (Fig. 2B). The oriental medicinal herbs, the mixture of oriental medicinal herbs compost, and vermicompost tea showed decreased in $\mathrm{NH}_{4}^{+}-\mathrm{N}$ nitrogen contents after incubation (Fig. 2B). Little change of $\mathrm{NH}_{4}^{+}{ }_{4} \mathrm{~N}$ nitrogen content was observed for rice straw compost and vermicompost tea after incubation (Fig. 2B).

In a research conducted by Gorlach and Mazur (2002), nitrogen losses were greater in applied fertilizer containing oxidized form of nitrogen $\left(\mathrm{NO}_{3}^{-}-\mathrm{N}\right)$ than in those containing reduced form of nitrogen $\left(\mathrm{NH}_{4}^{+}{ }_{4} \mathrm{~N}\right.$ and $\left.\mathrm{NH}^{2+}{ }_{2}-\mathrm{N}\right)$ present in physiologically acid fertilizers such as urea and ammonium sulfate. Owing to these chemical properties, nitrogen fertilizers could affect the soil $\mathrm{pH}$ and influence the availability of microelements and heavy metals in plants (Smole’n et al., 2012).

Microbial population density of compost tea. Culturable microbial population densities were significantly different between the compost materials (Fig. 3). Microbial communities of all aerated compost teas were predominantly bacteria (Fig. 3A). The average population densities of culturable bacteria increased in all the aerated compost teas for three days after incubation. Highest population density of culturable bacteria was recorded $1.5( \pm 13.6)-5.3( \pm 20.5)$ $\times 10^{7} \mathrm{cfu} / \mathrm{ml}$ in the mixture of oriental medicinal herbs compost and vermicompost tea during incubation (Fig. 3A)
However, fungal population densities were significantly lower than those of bacteria and significantly decreased in all compost teas after two days incubation. The highest population density of fungi was recorded $8.7( \pm 0.6)-24.7$ $( \pm 2.1) \times 10^{3} \mathrm{cfu} / \mathrm{ml}$ in the mixture of oriental medicinal herbs compost and vermicompost tea during incubation (Fig. 3A).

Ingham (2005) reported that aerated compost tea often added sugars, grain, fish emulsion, kelp tea, humic acid and other materials is enhanced microbial activity of the final brewing product. The compost extracts were undoubtedly harbored significant populations of biocontrol agents because they were prepared from mature composts, which typically are colonized by a great diversity of such microorganisms (Alvarez et al., 1995; Boehm et al., 1997; Bulluck and Ristaino, 2002; Hoitink et al., 1997; Hoitink and Boehm, 1999).

In the study, all compost teas exceeded the threshold and showed high microbial loads. Thus, all microbial groups with the exception of fungi have values greater than $10^{6}$ $\mathrm{cfu} / \mathrm{mL}$ or even around $10^{7} \mathrm{cfu} / \mathrm{ml}$.

The level of microbial population in compost teas necessary to determine suppressive level has been extensively studied (Diánez et al., 2007; Scheuerell and Mahaffee, 2004). Microbial communities inhabiting the compost colonized water extracts had proliferated during the compost tea incubation. Final aerated compost teas were applied in crops to achieve plant growth promotion and plant pathogen control. Also, Sylvia (2004) reported that compost extract containing high population of microbiota such as $R h i-$ zobacteria, Trichoderma, and Pseudomonas spp. enhanced the growth and yield of crops. Scheuerell and Mahaffee (2004) hypothesized that $10^{6} \mathrm{cfu} / \mathrm{ml}$ of culturable bacteria 


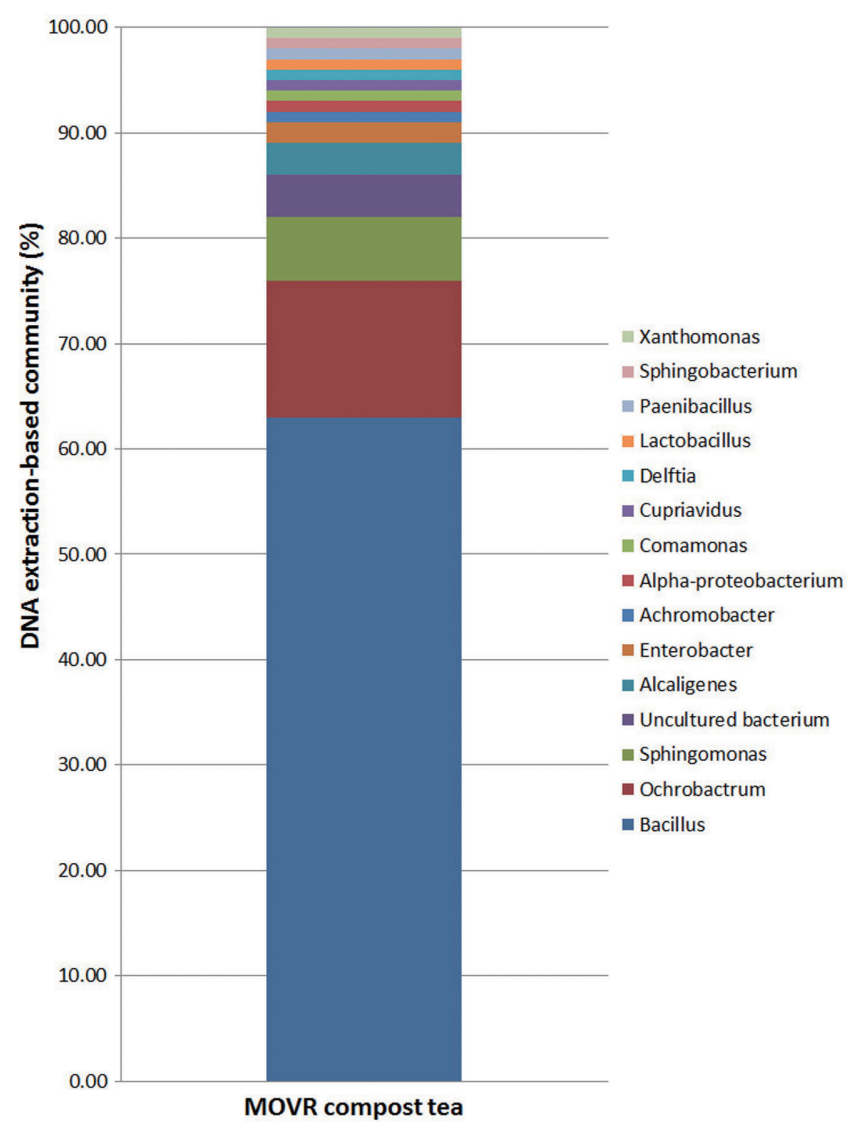

Fig. 4. Major bacterial populations detected in growing compost tea based on three compost mixtures with the oriental medicinal herbs compost, rice straw compost and vermicompost (MOVR) by $16 \mathrm{~S}$ rRNA sequencing of 100 strains. All of sequences for analyzed strains could be assigned with high confidence $(\geq 98.5 \%$ for isolates) to known genus. The relative abundance of each genus is shown as a percentage.

represents a transition, counting data from non-suppressive to suppressive compost teas.

The dominant bacterial groups of the MOVR compost tea. In the culture-dependent analysis of microbial diversity, 100 bacterial strains were isolated from MOVR compost tea and were identified as 15 groups including uncultured bacterium at the genus level by $16 \mathrm{~S}$ rDNA genebased sequences analysis. The dominant bacterial genera were Bacillus (63.0\%), Ochrobactrum (13.0\%), Spingomonas $(6.0 \%)$ and uncultured bacterium (4.0\%) in Fig. 4.

Ryckeboer et al. (2003) attempted to determine the microbial community of the dominant bacteria group and functional groups of microorganisms originated from composting of bio-waste, using incubation, isolation, and enumeration techniques. They reported that dominant bacteria groups were fungi, Streptomyces, and yeasts during the themorphilic phase of composting procedures. Bacillus genera was dominated during the peak-heating phase of fresh wastes.

Cahyani et al. (2003) reported that a successional trabsition of bacterial community groups: Alphaproteobacteria in the raw materials of rice straw compost, Bacillus and Actinomycetes at the thermophilic phase, and Cytophage and Clostridial groups at the middle and curing phase during composting of rice straw.

Growth promotion effect of compost tea on plant. Among the four compost teas, the mixture of oriental medicinal herbs compost and vermicompost tea (MOVR) had significantly higher levels of nitrogen content and microbial population density. Thus, MOVR was selected as the candidate compost tea for growth promotion test of plants in the study. Applications of the MOVR significantly increased shoot and root growths of the tested plant such as red leaf lettuce (Table 1), sweet corn (Table 2) and soybean (Table 3, Fig. 3) compared to the untreated control. The fresh weight of the upper part of red leaf lettuce foliage was significantly greater at $0.4 \%$ MOVR than the other MOVR concentration (Table 1). The effect of four MOVR concentrations $(0.1 \%, 0.2 \%, 0.4 \%$, and $0.8 \%)$ on shoot growth of the red leaf lettuce resulted in greater leaf number, length and width than the untreated control (Table 1). Application

Table 1. Growth characteristics of red leaf lettuce by different concentration of the mixture of oriental medicinal herbs compost, rice straw compost and vermicompost tea (MOVR), $0.1 \%, 0.2 \%, 0.4 \%$, and $0.8 \%$ in greenhouse. Means followed by the same letter are not significantly different $(p<0.05)$ within each concentration

\begin{tabular}{lcccc}
\hline \multirow{2}{*}{ Treatment } & \multicolumn{3}{c}{ Lettuce leaf } \\
\cline { 2 - 5 } & number & length $(\mathrm{cm})$ & width $(\mathrm{cm})$ & fresh weight $(\mathrm{g})$ \\
\hline MOVR 0.1\% & $10.7 \mathrm{c}$ & $16.7 \mathrm{c}$ & $11.4 \mathrm{c}$ & $351.5 \mathrm{~d}$ \\
MOVR 0.2\% & $12.1 \mathrm{bc}$ & $17.5 \mathrm{bc}$ & $13.6 \mathrm{~b}$ & $540.2 \mathrm{c}$ \\
MOVR 0.4\% & $16.2 \mathrm{a}$ & $23.3 \mathrm{a}$ & $18.2 \mathrm{a}$ & $872.9 \mathrm{a}$ \\
MOVR 0.8\% & $13.4 \mathrm{~b}$ & $19.1 \mathrm{~b}$ & $15.2 \mathrm{ab}$ & $653.8 \mathrm{~b}$ \\
Untreated control & $10.2 \mathrm{c}$ & $14.0 \mathrm{~d}$ & $10.1 \mathrm{~d}$ & $250.2 \mathrm{e}$ \\
\hline
\end{tabular}


Table 2. Effect of different concentration of the mixture of oriental medicinal herbs compost, rice straw compost and vermicompost tea (MOVR), $0.1 \%, 0.2 \%, 0.4 \%$, and $0.8 \%$ in greenhouse on sweet corn growth in greenhouse. Means followed by the same letter are not significantly different $(p<0.05)$ within each concentration

\begin{tabular}{lccccc}
\hline & \multicolumn{3}{c}{ Sweet corn } \\
\cline { 2 - 4 } Treatment & \multicolumn{3}{c}{ Root } & & \multicolumn{2}{c}{ Shoot } \\
\cline { 2 - 3 } \cline { 5 - 6 } & Length $(\mathrm{cm})$ & Fresh weight $(\mathrm{g})$ & & Length $(\mathrm{cm})$ & Fresh weight $(\mathrm{g})$ \\
\hline MOVR 0.1\% & $4.1 \mathrm{~d}$ & $12.8 \mathrm{~d}$ & & $20.7 \mathrm{~d}$ & $370.5 \mathrm{~d}$ \\
MOVR 0.2\% & $5.2 \mathrm{c}$ & $14.6 \mathrm{c}$ & & $25.0 \mathrm{c}$ & $420.0 \mathrm{c}$ \\
MOVR 0.4\% & $6.8 \mathrm{~b}$ & $20.1 \mathrm{~b}$ & & $30.1 \mathrm{~b}$ & $530.8 \mathrm{~b}$ \\
MOVR 0.8\% & $9.1 \mathrm{a}$ & $24.6 \mathrm{a}$ & & $35.3 \mathrm{a}$ & $720.9 \mathrm{a}$ \\
Untreated control & $2.9 \mathrm{e}$ & $10.8 \mathrm{e}$ & & $16.0 \mathrm{e}$ & $260.2 \mathrm{e}$ \\
\hline
\end{tabular}

Table 3. Plant responses to different concentration of the compost tea (MOVR) based on the oriental medicinal herbs compost, rice straw compost and vermicompost in the root and shoot growth and nodule number, as compared to untreated control at 45 days old soybean plant in greenhouse. Means followed by the same letter are not significantly different $(p<0.05)$ within each concentration

\begin{tabular}{|c|c|c|c|c|c|}
\hline \multirow{3}{*}{ Treatment } & \multicolumn{4}{|c|}{ Soybean } & \multirow{3}{*}{ Nodule number } \\
\hline & \multicolumn{2}{|c|}{ Root } & \multicolumn{2}{|c|}{ Shoot } & \\
\hline & length $(\mathrm{cm})$ & weight (g) & height $(\mathrm{cm})$ & fresh weight (g) & \\
\hline MOVR $0.1 \%$ & $12.9 \mathrm{~d}$ & $18.7 \mathrm{c}$ & $20.8 \mathrm{c}$ & $81.7 \mathrm{~d}$ & $23.4 \mathrm{~d}$ \\
\hline MOVR $0.2 \%$ & $15.6 \mathrm{c}$ & $23.0 \mathrm{~b}$ & $24.5 \mathrm{~b}$ & $97.3 \mathrm{c}$ & $42.1 \mathrm{c}$ \\
\hline MOVR $0.4 \%$ & $19.1 \mathrm{~b}$ & $23.5 \mathrm{~b}$ & $26.9 \mathrm{~b}$ & $129.6 \mathrm{~b}$ & $106.3 \mathrm{~b}$ \\
\hline MOVR $0.8 \%$ & $24.1 \mathrm{a}$ & $53.5 \mathrm{a}$ & $30.9 \mathrm{a}$ & $157.1 \mathrm{a}$ & $164.5 \mathrm{a}$ \\
\hline Untreated control & $8.0 \mathrm{e}$ & $14.2 \mathrm{~d}$ & $14.4 \mathrm{~d}$ & $63.6 \mathrm{e}$ & $5.4 \mathrm{e}$ \\
\hline
\end{tabular}

of $0.8 \%$ MOVR concentration significantly increased the growth of root and shoot of both sweet corn (Table 2) and soybean (Table 3). The soybean treated with higher MOVR concentration was more effective in increasing the root nodule formation by 7.25 times than in the lower MOVR concentrations (Table 3 and Fig. 5).

Similar results were demonstrated that vermicompost tea found to increase plant growth best under laboratory tests was applied to cereals (wheat and barley) and vegetables (Raphanus sativus, Rucola selvatica, and Pisum sativum) in a field study (Fritz et al., 2012).

Efficacy of compost extracts may vary considerably. This may be due to differences in procedures used for preparation of the compost extracts, the source, nutrient composition, quality, and maturity of the compost (Weltzien, 1992) According to research compiled at the Kentucky State University, nutrients in compost tea have been detected in plant roots as early as one hour immediately after application (Micheal, 2001). The liquid fertilizer directly applied to the plant's foliage quickly provided the cell tissues with nutrients. This reaction was in contrast with the slower and indirect path taken by building soil structure through solid compost. Misting plants with compost tea is a more effec-

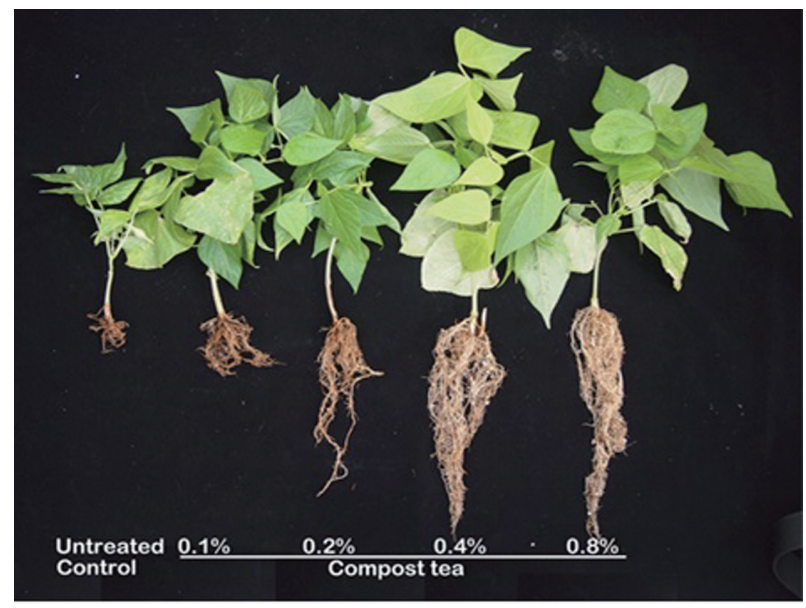

Fig. 5. Growth promotion effects of the compost tea based on three compost mixtures (MOVR) with the oriental medicinal herbs compost, rice straw compost and vermicompost on soybean growth for 45 days at one week interval of foliar application of four concentration, $0.1 \%, 0.2 \%, 0.4 \%$ and $0.8 \%$ MOVR in the greenhouse.

tive method for delivering nutrients thereby boosting than drenching the soil (Arancon et al., 2006; Gonález et al., 
2010).

More so, vermicomposting or composting with earthworms is an excellent technique for improving the physical, chemical and biological properties of the soil. Also, use of vermicompost promotes germination growth and flowering and increases the yields of horticultural crops, tomatoes, peppers, strawberries, foliage crops, and others (Litterick et al., 2004; Ryan et al., 2005)

Consequently, altered solubility of mineral nutrients occurred and manifested as an increased content of easily available forms of microelements, heavy metals and trace elements in soil. As a result, water-based compost tea enhanced the uptake and accumulation of nutrient elements in the plant (Rodríguez-Ortíz et al., 2006). Microbial communities present in compost tea may also induce disease resistance as well as stimulate nutrient uptake and plant growth (Ingham, 2005; Scheuerell and Mahaffee, 2002).

In the study, application of aerated compost tea from organic compost based using MOVR (the mixture of rice straw compost, vermicompost, and Hinoki cypress bark compost) to the root zone increased the plant shoot and root growths and yield of the red leaf lettuce, sweet corn, and soybean. Thus, compost tea could be used as an agent for promoting plant growth in organic cultivation of crops.

\section{Acknowledgments}

This study was carried out with the support of the Research program for Agricultural Science \& Technology Development (Project No. PJ00843603), funded by the Rural Development Administration, Republic of Korea in 2015.

\section{References}

Abbasi, P. A., Al-Dahmani, J., Sahin, F., Hoitink, H. A. J. and Miller, S. A. 2002. Effect of compost amendments on disease severity and yield of tomato in conventional and organic production systems. Plant Dis. 86:156-161.

Abu-Zahra, T. R. and Tahboub, A. B. 2008. Effect of organic matter sources on chemical properties of the soil and yield of strawberry under organic farming conditions. World Appl. Sci. J. 5:383-388.

Al-Dahmani, J. H., Abbasi, P. A., Miller, S. A. and Hoitink, H. A. J. 2003. Suppression of bacterial spot of tomato with foliar sprays of compost extracts under greenhouse and field conditions. Plant Dis. 87:913-919.

Alvarez, M. A., Gagné, S. and Antoun, H. 1995. Effect of compost on rhizosphere microflora of the tomato and on the incidence of plant growth-promoting rhizobacteria. Appl. Environ. Microbiol. 61:194-199.

Arancon, N. Q., Edwarss, C. A. and Bierman, P. 2006. Influences of vermicomposts on field strawberries: Part 2. Effects on soil microbiological and chemical properties. Bioresour. Technol. 97:831-840.

Bauer, A. and Black, A. L. 1994. Quantification of the effect of soil organic matter content on soil productivity. Soil Sci. Soc. AM. J. 5:185-193.

Boehm, M. J., Wu, T., Stone, A. G., Kraakman, B., Iannotti, D. A., Wilson, G. E., Madden, L. V. and Hoitink, H. A. J. 1997. Crosspolarized magic-angle spinning 13C nuclear magnetic resonance spectroscopic characterization of soil organic matter relative to culturable bacterial species composition and sustained biological control of Pythium root rot. Appl. Environ. Microbiol. 63:162-168.

Brinton, W., Storms, P., Evans, E. and Hill, J. 2004. Compost teas: microbial hygiene and quality in relation to method of preparation. J. Biodynamics 2:36-45.

Brown, J. R., Christy, M. and Smith, G. S. 1993. Nitrate in soils and plants. Missouri University Extension. http://muextension.missouri.edu/xplor/agguides/agchem/g09804. htm/.

Bulluck, L. R., III and Ristaino, J. B. 2002. Effect of synthetic and organic soil fertility amendments on southern blight, soil microbial communities, and yield of processing tomatoes. Phytopathology 92:181-189.

Conforti, C., Marney, B., Hutchis, K. and Koch, J. 2002. The effects of compost tea on golf course greens turf and soil. Publication by Presidio Golf Course and Arnold Palmer Golf Management Company, San Francisco, CA, U.S.A.

Diánez, F., Santos, M. and Tello, J. C. 2007. Suppressive effects of grape marc compost on phytopathogenic oomycetes. Arch. Phytopathology Plant Protect. 40:1-18.

Diver, S. 2002. Notes on compost teas: A supplement to the ATTRA publication "Compost teas for plant disease control." Appropriate Technology Transfer for Rural Areas.

Duxbury, J. M., Smith, M. S. and Doran, J. W. 1989. In: Soil organic matter as a source and sink of plant nutrients, eds. by Coleman, D. C., Oades, J. M., Uehara, G., pp. 33-67. Dynamics of soil organic matter in tropical ecosystem, USA, University of Hawaii Press.

Fritz, J. I., Franke-Whittle, I. H., Haindl, S., Insam, H. and Braun, R. 2012. Microbiological community analysis of vermicompost tea and its influence on the growth of vegetables and cereals. Can. J. Microbiol. 58:836-847.

Gonález, M., Gomez, E, Comesea, R., Quesada, M. and Contia, M. 2010. Influence of organic amendments on soil quality potential indicators in an urban horticultural system. Bioresour. Technol. 101:8897-8901.

Goonani, Z., Sharifi, K. and Riahi, H. 2011. The effects of spent mushroom compost and municipal solid waste compost on Phytophthora drechsleri in vivo and in vitro. Arch. Phytopathology Plant Protect. 44:1171-1181.

Gorlach, E. and Mazur, T. 2002. Chemia rolna. Wyd. Nauk. PWN, Warszawa (in Polish).

Haggag, W. M. and Saber, M. S. M. 2007. Suppression of early blight on tomato and purple blight on onion by foliar speays 
of aerated and non-aerated compost teas. J. Food Agric. Environ. 5:302-309.

Hamdar, B. C. and Rubeiz, I. G. 2000. Organic farming: Economic efficiency approach of applying layer litter rates to greenhouse grown strawberries and lettuce. Small Fruits Rev. 1:3-14.

Hoitink, H. A. J. and Boehm, M. J. 1999. Biocontrol within the context of soil microbial communities: A substrate-dependent phenomenon. Annu. Rev. Phytopathol. 37:427-446.

Hoitink, H. A. J., Stone, A. G. and Han, D. Y. 1997. Suppression of plant diseases by composts. HortScience 32:184-187.

Ingham, E. R. 2000. The compost tea brewing manual, Unisum Communications, Corvallis, OR..

Ingham, E. R. 2005. The Compost Tea Brewing Manual ( $\left.5^{\text {th }}\right)$. Soil Food International Inc.

Ingram, D. T. and Millner, P. D. 2007. Factors affecting compost tea as a potential source of Escherichia coli and Salmonella on fresh produce. J. Food Protect. 70:828-834.

Kannangara, T., Forge, T. and Dang, B. 2006. Effects of aeration, molasses, kelp, compost type, and carrot juice on the growth of Escherichia coli in compost teas. Compost Sci. Util. 14:40-47.

Kim, B. Y., Weon, H. Y., Park, I. C., Lee, S. Y., Kim, W. G. and Song, J. K. 2011. Microbial diversity and community analysis in lettuce or cucumber cultivated greenhouse soil in Korea. Kor. J. Soil Sci. Fet. 44:1169-1175.

Koné, S. B., Dionne, A., Tweddell, R. J., Antoun, H. and Avis, T. J. 2010. Suppressive effect of non-aerated compost teas on foliar fungal pathogens of tomato. Biol. Control 52:167-173.

Litterick, A., Harrier. L., Wallance, P., Watson, C. A. and Wood, M. 2004. The role of uncomposted materials, composts, manures and compost extracts in reducing pest and disease incidence and severity in sustainable temperate agricultural and horticultural crop production- a review. Plant Sci. 23:453-479.

McConnell, D. B., Shiralipour, A. and Smith, W. H. 1993. Compost application improves soil properties. BioCycle 34:61-63.

Merrill, R. and McKeon, J. 2001. Apparatus design and experimental protocol for organic compost teas. Organic Farming Research Foundation 9:9-15.

Michael, B. 2001. "Compost tea". Paper presented at the 2001 Kentucky fruit and vegetable conference and trade show for Kentucky State Horticulture Society and Kentucky Vegetable Growers Association, Lexington, K.Y. January 8-9.

Naidu, Y., Meon, S., Kadir, J. and Siddiqui, Y. 2010. Microbial starter for the enhancement of biological activity of compost tea. Int. J. Agr. Biol. 12:51-56.

Palmer, A. K., Evans, K. J. and Metcalf, D. A. 2010. Characters of aerated compost tea from immature compost that limit colonization of bean leaflets by Botrytis cinerea. J. Appl. Microbiol. 109:1619-1631.

Pant, A., Radovich, T. J. K., Hue, N. V. and Arancon, N. Q. 2011. Effects of vermicompost tea (aqueous extract) on Pak Choi yield, quality, and on soil biological properties. Compost Sci. Util. 19:279-292.
Pharand, B., Carisse, O. and Benhamou, N. 2002. Cytological aspects of compostmediated induced resistance against crown and root rot in tomato. Phytopathology 92:424-438.

Rahel, C. B., Thomas, K., Thomas, D. B., Markus, Z., Sandra, H., Didier, O., Josef, M., Christian, S., Saverio, L., Peter, S., Urs, B., Patrick, E., Michael, O., Franz, X. S. and Joseph, T. 2007. Organic pollutants in compost and digestate. Part 2. Polychlorinated dibenzo-p-dioxins, and -furans, dioxin-like polychlorinated biphenyls, brominated flame retardants, perfluorinated alkyl substances, pesticides, and other compound. J. J. Environ. Monit 9: 465-472.

Rodríguez-Ortíz, J. C., Valdez-Cepeda, R. D., Lara-Mireles, J. L., Rodríguez-Fuentes, H., Vázquez-Alvarado, R. E., Magallanes-Quintanar, R. and García-Hernández, J. L. 2006. Soil nitrogen fertilization effects on phytoextraction of cadmium and lead by tobacco (Nicotiana tabacum L.). Biorem 10:105114.

Ryan, M., Wilson, S., Hepperly, P., Travis, J., Halbrendly, N. and Wise, A. 2005. Compost tea potential is still brewing. Biocyle 46:30-32.

Ryckeboer, J., Mergaert, J., Coosemans, J., Deprins, K. and Swings, J. 2003. Microbiological aspects of biowaste during composting in monitored compost bin. J. Appl. Microbiol. 94:127-137.

Scheuerell, S. J. and Mahaffee, W. F. 2002. Compost tea principals and prospects for plant disease control. Compost Sci. Util. 10:313-338.

Scheuerell, S. J. and Mahaffee, W. F. 2004. Compost tea as a container medium drench for suppressing seedling damping-off caused by Pythium ultimum. Phytopathology 94:1156-1163.

Scheuerell, S. J. and Mahaffee, W. F. 2006. Variability associated with suppression of gray mold (Botrytis cinerea) on geranium by foliar applications of non-aerated and aerated compost teas. Plant Dis. 90:1201-1208.

Smith, N. R. and Dawson, V. T. 1944. The bacteriostatic action of rose bengal in media used for the plate counts of soil fungi. Soil Sci. 58:467-471.

Smole'n, S., Sady, W. and Wierzbi'nska, J. 2012. The influence of nitrogen fertilization with entec-26 and ammonium nitrate on the concentration of thirty-one elements in carrot (Daucus carota L.) storage roots. J. Elementol. 17:115-137.

Steinegger, D. H. and Janssen, D. E. 1996. Straberries, plants, selecting and preparing a site, planting and care of strawberries. Institute of Agriculture and Natural Resources, University of Nebraska-Lincoln, pp. 889-897.

Sylvia, E. W. 2004. The effect of compost extract on the yield of strawberries and severity of Botrytis cinerea. J. Sustain. Agr., 25:57-68.

Termorshuizen, A. J., van Rijn, E., vander Gaag, D. J., Alabouvette, C., Chen, Y., Lagerlof, J., Malandrakis, A. A., Paplomatas, E. J., Ramert, B., Ryckeboer, J., Steinberg, C. and ZmoraNahum, S. 2006. Suppressiveness of 18 composts against 17 pathosystems: variability in pathogen response. Soil Biol. Biochem. 38:2461-2477. 
Turemis, N. 2002. The effects of different organic deposits on yield and quality of strawberry cultivar Dorit (216). Acta Hort. 567:507-510.

Uehara, G. and Gilman, G. 1981. The mineralogy, chemistry and physics of tropical soils with variable charge clays. Boulder, USA, Westview Press.

Weisburg, W. G., Barns, S. M., Pelletier, D. A. and Lane, D. J. 1991. 16S ribosomal DNA amplification for phylogenetic study. J. Bacteriol. 173:697-703.

Weltzien, H. C. 1992. Biocontrol of foliar fungal disease with compost extracts. In: Microbial Ecology of Leaves, ed. by Andres, J.H., Hirano, S.S., pp. 430-450. Springer-Verlag, New York.

Zaller, J. G. 2006. Foliar spraying of vermicompost extracts: Effects on fruit quality and indications of late-blight suppression of field-grown tomatoes. Biol. Agric. Hortic. 24:165-180. 